\title{
HIV-1 SUBTYPES AND MUTATIONS ASSOCIATED TO ANTIRETROVIRAL DRUG RESISTANCE IN HUMAN ISOLATES FROM CENTRAL BRAZIL
}

\author{
Daniela Marreco Cerqueira ${ }^{1}$, Eduardo Dias Ramalho $^{1}$; Claudiner Pereira Oliveira ${ }^{1}$; Ruiter Roberto Silva ${ }^{2}$; \\ Miriam Franchini²; Maria Sueli Soares Felipe ${ }^{1}$; Cláudia Renata Fernandes Martins ${ }^{1 *}$
}

\author{
${ }^{1}$ Departamento de Biologia Celular, Instituto de Biologia, Universidade de Brasília, DF, Brasil; ${ }^{2}$ Laboratório \\ Central de Saúde Pública do Distrito Federal - LACEN, Brasília, DF, Brasil.
}

Submitted: June 09, 2003; Returned to authors for corrections: March 04, 2004; Approved: July 28, 2004.

\begin{abstract}
The detection of polymorphisms associated to HIV-1 drug-resistance and genetic subtypes is important for the control and treatment of HIV-1 disease. Drug pressure selects resistant variants that carry mutations in the viral reverse transcriptase (RT) and protease (PR) genes. For a contribution to the public health authorities in planning the availability of therapeutic treatment, we therefore described the genetic variability, the prevalence of mutations associated to drug resistance and the antiretroviral resistance profile in HIV-1 isolates from infected individuals in Central Brazil. Nineteen HIV-1 RNA samples from a Public Health Laboratory of the Federal District were reversely transcribed and cDNAs were amplified by nested PCR. One fragment of $297 \mathrm{bp}$ coding the entire protease gene, and another of $647 \mathrm{bp}$, corresponding to the partial RT gene (codons 19-234), were obtained. Automated sequencing and BLAST analysis revealed the presence of 17 B and 2 F1 HIV-1 subtypes. The amino acid sequences were analyzed for the presence of resistance-associated mutations. A total of 6 PR mutations, 2 major and 4 accessory, and 8 RT mutations related to drug resistance were found. Our data suggest a high prevalence of HIV-1 B subtype in the studied population of Federal District as well as the presence of genetically-resistant strains in individuals failing treatment.
\end{abstract}

Key words: HIV-1, drug resistance, antiretroviral drugs

\section{INTRODUCTION}

According to the Joint United Nations Programme on HIV/ AIDS (UNAIDS) and the World Health Organisation (WHO), 42 million people throughout the world were estimated to be living with HIV/AIDS at the end of 2002. Brazil accounts for 237,580 AIDS cases registered between 1980 and March 2002 and approximately 600,000 individuals are currently infected by HIV (5).

HIV is a highly polymorphic virus, due mainly to the errorprone reverse transcriptase, the high replication rate of the virus and the highly selective pressure of the specific antiretroviral drugs $(4,24,27,29)$. Three groups are present in the HIV-1 global pandemic: ' $\mathrm{M}$ ', the main group, ' $\mathrm{O}$ ', the outlier, and ' $\mathrm{N}$ ', the
Non-M/Non-O. The M group is further subdivided into 11 subtypes (A-K) and 14 circulating recombinant forms (CRFs) $(18,20,29)$. Such diversity has potential implications for vaccine design as well as for diagnostics, pathogenesis and epidemiology (19).

Pairwise nucleotide distances among the HIV-1 subtypes may reach $20 \%$ in env, $16 \%$ in gag and $13 \%$ in the pol gene (18). In general, the $g a g$ and/or env are used for subtyping, as these genes are more diverse than pol $(3,29)$. However, many reports have shown that subtypes based on the pol genes reverse transcriptase (RT) and protease (PR) are usually the same as the subtype of the gag gene of these isolates (12).

Certain polymorphims in HIV-1 genes, which are targeted by antiretroviral drugs, can confer drug resistance (13). Drug

*Corresponding author: Mailing address. Secretaria de Biologia Celular, Instituto de Biologia, Universidade de Brasília, Asa Norte. 70919-900, Brasília, DF, Brasil. Tel.: (+5561) 307-2191; Fax: (+5561) 272-1793. E-mail: cmartins@unb.br 
resistance is the leading cause of treatment failure (1) and the widespread use of antiviral drugs has led to an increased prevalence of HIV-1 resistant strains after prolonged therapy. Besides, transmission of drug-resistant HIV-1 viruses has also been documented (16,27).

Viral resistance can be reasonably predicted on the basis of the RT and PR genotype by identifying mutations known to confer resistance to specific compounds as well as mutations involved in modulating resistance (21). At the PR gene, the distinction between major and accessory mutations is important because those that are listed as major usually confer drug resistance by themselves and have greater effects on drug susceptibility than those that are listed as accessory, which could improve the fitness of virus containing major mutations $(1,4,13,14,24,27,33)$.

Mutations associated to resistance have been identified for the three major antiretroviral drug classes: nucleoside reverse transcriptase inhibitors (NRTI), non-nucleoside reverse transcriptase inhibitors (NNRTI) and protease inhibitors (PI). Some NRTI may have their activity reduced due to single point mutations in the RT gene or a number of RT mutations may be required to confer significant resistance to others NRTI. For the NNRTI, resistance can be conferred by single point mutations in RT. Otherwise, multiple mutations are usually required in the PR gene before resistance to PI develops $(10,11)$.

At present there is little information available concerning the HIV-1 genetic diversity in Central Brazil (30). The aim of this study was to deepen the knowledge about HIV-1 genetic diversity in Central Brazil through sequencing the protease and reverse transcriptase virus genes. We evaluated the polymorphisms and subtypes of these genes and described their resistance profile among HIV-1 isolates from infected individuals in the Federal District.

\section{MATERIALS AND METHODS}

HIV-1 RNA samples from 19 infected individuals were collected at a Public Health Laboratory located at the Federal District during 1998. All samples belonged to individuals who had viral load counts higher than 30,000 copies/ml and were, according to this laboratorial evidence, failing antiretroviral therapy.

Viral RNA was extracted from plasma samples using the Nucleon-HT kit (Organon-Teknika). The viral RNA was denatured for cDNA synthesis. The cDNA was used as template in nested PCR amplification of the full-length PR gene and of a fragment of the RT gene (codons 19-234). Protease first round primers were DP10/DP11 (5'TAACTCCCTCTC AGAAG CAGGAGCCG3'/5'CCATTCCTGGCTTTAATTTTACTGGTA3') and second round were DP16/DP17 (5'CCTCAAATCACT CTTTGGCAAC3'/5' AAAATTTTAAAGTG CAGCCAAT3'). To partially amplify the RT gene, we used RT09/RT12 (5'GTA
CAGTATT AGTAGGACCTACACCTGTC3'/5'ATCA GGA TGGAGTTCATAACCCATCCA3') in the first round and RT01/ RT04 (5'CCAAAAGTTAAACAATGG CCATTGACAG A3' / 5'AGTT CATAACCCATCCAAAG3') in the second. The PCR products with the internal primer pairs for amplification of the RT and PR genes were fragments of 647 base pairs (bp) and 297 bp, respectively.

The PCR products were directly sequenced using the inner PCR primer set and its nucleotide sequences were determined automatically by the Taq Dye-terminator method, in a Megabace System (Amersham-Pharmacia). Forward and reverse sequences were generated. Sequence edition and alignments, as well as translations, were performed using CLUSTAL W (32). Minor manual adjustments were made to improve the alignments.

Virus subtypes were determined by comparing the protease and RT DNA sequences of HIV-1 isolates to reference sequences. Subtype sequence homologies were examined using the Basic Local Alignment Search Tool (BLAST) algorithm (2). Protease and RT sequences were analyzed for the presence of amino acid polymorphisms. Resistance mutations were identified using resistance analysis tools available over the Internet (Beta Test at HIV RT and Protease Sequence Database) (28). Mutations associated with resistance to protease and to nucleoside and non-nucleoside RT inhibitors were defined in agreement with recent International AIDS Society-USA Panel drug resistance testing guidelines (13). At the protease gene, resistance mutations were classified as major or accessory. Interpretation of genotypic data was manually performed using a set of rules based on genotypic-phenotypic resistance data available from the literature, as indicated by the International AIDS Society (13).

\section{RESULTS}

All of the 19 samples gave positive PCR products for the protease and RT genes. Of the studied population, 17 individuals $(89.5 \%)$ were infected with HIV-1 subtype B, considering the genetic information derived from the PR and RT genes. The two other samples (10.5\%) showed discordant PR and RT subtyping, being PR B / RTF1.

Resistance mutations in the PR and / or RT genes of HIV-1 were detected in $84.2 \%$ of the patients (16) that were not responding to antiretroviral therapy with the methods employed in this study. For the remaining $15.8 \%$ (3), resistance mutations were not detected. Major mutations for protease inhibitors were described in $36.8 \%$ of the patients (7) and the other $26.3 \%$ (5) showed only accessory substitutions.

The distribution of HIV-1 resistance-associated mutations in the RT and PR genes is shown in Fig. 1. Six resistance mutations were found at the PR gene. Among them, two were major and four were accessory mutations. Major ones occurred at codons M46I (5.3\%), and I50V (31.6\%) and accessory 
occurred at M36I (5.3\%), L63P(31.6\%), A71T (10.5\%), and V77I $(5.3 \%)$. At the RT gene, mutations associated with NRTI resistance were M41L (5.3\%), D67N (21\%), K70R (31.6\%), V118I (21\%), M184V (21\%), L210W (10.5\%), T215Y/F (15.8\%), and K219Q (5.3\%). No mutations associated to NNRTI resistance were found. The results presented in Table 1 indicate that, beyond the resistance-associated mutations found within the

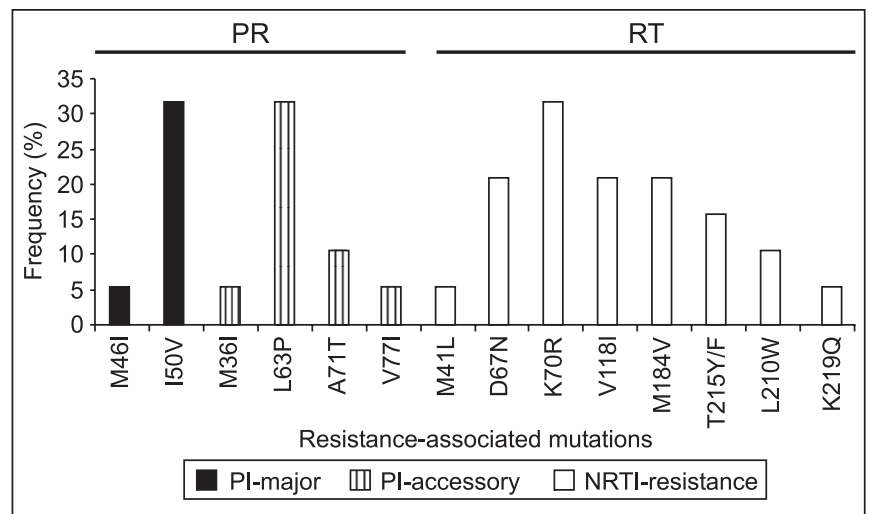

Figure 1. Frequency of protease (PR) and reverse transcriptase (RT) resistance mutations associated to PR inhibitors (PI) and to nucleoside RT inhibitors (NRTI) resistance.

Table 1. Frequency of polymorphisms in the protease (PR) and reverse transcriptase (RT) genes.

\begin{tabular}{|c|c|c|c|}
\hline $\begin{array}{l}\text { Mutations at } \\
\text { the PR gene }\end{array}$ & $\mathrm{N}^{\mathrm{o}}(\%)$ & $\begin{array}{l}\text { Mutations at } \\
\text { the RT gene }\end{array}$ & $\mathrm{N}^{\mathrm{o}}(\%)$ \\
\hline E35D & $2(10.5)$ & V35T & $2(10.5)$ \\
\hline N37S & $14(73.7)$ & $\mathrm{T} 39 \mathrm{~K} / \mathrm{I}$ & $3(15.8)$ \\
\hline F53L & $2(10.5)$ & $\mathrm{I} 50 \mathrm{M}$ & $2(10.5)$ \\
\hline \multirow[t]{17}{*}{$\mathrm{K} 70 \mathrm{R} / \mathrm{E}$} & $2(10.5)$ & A98G/S & $2(10.5)$ \\
\hline & & K102Q & $2(10.5)$ \\
\hline & & K122E & $5(26.3)$ \\
\hline & & D123E & $6(31.6)$ \\
\hline & & I135T/V & $12(63.2)$ \\
\hline & & S162C & $2(10.5)$ \\
\hline & & E169D & $2(10.5)$ \\
\hline & & $\mathrm{K} 173 \mathrm{D} / \mathrm{T}$ & $2(10.5)$ \\
\hline & & Q174K & $2(10.5)$ \\
\hline & & D177G/E & $6(31.6)$ \\
\hline & & I195K/L & $2(10.5)$ \\
\hline & & T200R/A/I & $5(26.3)$ \\
\hline & & $\mathrm{I} 202 \mathrm{~V}$ & $5(26.3)$ \\
\hline & & E204G/D/K & $3(15.8)$ \\
\hline & & Q207E & $2(10.5)$ \\
\hline & & $\mathrm{R} 211 \mathrm{~K}$ & $5(26.3)$ \\
\hline & & $\mathrm{F} 214 \mathrm{~L} / \mathrm{Y}$ & $5(26.3)$ \\
\hline
\end{tabular}

PR and RT regions, many other polymorphisms were detected. These amino acid variants at polymorphic positions do not cause drug resistance by themselves and emerge as genetic variants with apparently equivalent replication capacity (14). At the PR gene, the most frequent polymorphism was N37S (73.7\%). Moreover, $63.2 \%$ of the RT genotypes sequenced showed the polymorphism I135T/V. Mutations at position 135 have been shown to cause low-level resistance to NNRTI, particularly when present in combination but by themselves do not appear to influence the virologic response to an NNRTIcontaining regimen (7).

The inferred levels of resistance to the FDA-approved antiHIV drugs were deduced from the amino acid sequences and are summarized in Table 2. For all samples, the PR and RT regions were classified as susceptible, with intermediate resistance or resistant to each of the antiretroviral drugs. Six patients (31.6\%) carried viruses predicted to be susceptible to all analyzed PI, NRTI and NNRTI. No patients had viruses classified as resistant to all of these drugs. Viruses that were predicted to be sensitive to all PI were found in $63.2 \%$, to all NRTI in $52.6 \%$, and to all NNRTI in $100 \%$ of the individuals studied here. The highest prevalence of resistance was found to the PI APV (36.8\%), followed by the NRTIAZT (26.3\%).

\section{DISCUSSION}

Brazil is a very large country and variations in the pattern of HIV-1 subtypes distribution have been identified among different geographic regions (18). This distribution has local determinants, and data from one site cannot be generalized for the entire country or to different geographic regions (25).

Many reports have shown that PR and RT genes of worldwide isolates are substantially different from each other to allow subtype grouping (12). In the present study, HIV-1 subtypes were determined by sequencing PR and RT genes of plasma viruses, an approach that has proved useful by other investigators, and allows the assessment for the presence of drug resistance substitutions $(15,23)$.

The predominance of B subtype (89.5\%) was previously reported in Brazil $(9,6,17,30)$. The two other discordant subtypes for the $\mathrm{PR}$ and $\mathrm{RT}$ genes may represent $\mathrm{B} / \mathrm{F}$ recombinant viruses. This result is also in agreement with the distribution of HIV-1 subtypes in Brazil, where non-B virus strains are frequently found and those from clade $\mathrm{F}$ are the second most prevalent one $(18 \%)$. Mosaics B/F, B/C, and B/D have also been reported in our country $(6,26,31)$.

Viral polymorphisms are commonly seen in virus populations of infected individuals. These nucleotide differences may have no impact on replication capacity, they may be deleterious (variants replicating less well or not at all), or confer replicative advantage. Moreover, this pool of genetic variants is able to adapt rapidly to changing selective pressures (14). As usual in 
Table 2. Inferred levels of resistance* to protease (PI) and to nucleoside reverse transcriptase (NRTI) inhibitors**.

\begin{tabular}{|c|c|c|c|c|c|c|c|c|c|c|c|c|c|}
\hline \multirow[t]{2}{*}{ Samples } & \multicolumn{6}{|c|}{ PI } & \multicolumn{7}{|c|}{ NRTI } \\
\hline & APV & IDV & NFV & RTV & SQV & LPV & $3 \mathrm{TC}$ & $\mathrm{ABC}$ & $\mathrm{AZT}$ & $\mathrm{D} 4 \mathrm{~T}$ & DDC & DDI & $\mathrm{TDF}$ \\
\hline Bsb05 & $S$ & $\mathrm{~S}$ & $S$ & $\mathrm{~S}$ & $S$ & $\mathrm{~S}$ & $\mathrm{~S}$ & $\mathrm{~S}$ & $\mathrm{~S}$ & $\mathrm{~S}$ & $\mathrm{~S}$ & $\mathrm{~S}$ & $\mathrm{~S}$ \\
\hline Bsb10 & $\mathrm{R}$ & S & S & S & S & I & S & I & $\mathrm{R}$ & I & S & S & I \\
\hline Bsb13 & $\mathrm{R}$ & $\mathrm{S}$ & $\mathrm{S}$ & $\mathrm{S}$ & $\mathrm{S}$ & I & $\mathrm{S}$ & $\mathrm{S}$ & $S$ & $\mathrm{~S}$ & $\mathrm{~S}$ & $\mathrm{~S}$ & $\mathrm{~S}$ \\
\hline Bsb16 & S & S & S & S & S & S & S & S & S & S & S & S & S \\
\hline Bsb18 & $\mathrm{R}$ & S & S & S & S & I & S & I & $\mathrm{R}$ & I & S & S & S \\
\hline Bsb19 & $\mathrm{R}$ & $\mathrm{S}$ & $S$ & $\mathrm{~S}$ & $\mathrm{~S}$ & I & $\mathrm{S}$ & $\mathrm{S}$ & $S$ & $\mathrm{~S}$ & $\mathrm{~S}$ & $\mathrm{~S}$ & $S$ \\
\hline Bsb20 & $\mathrm{S}$ & $\mathrm{S}$ & $\mathrm{S}$ & $\mathrm{S}$ & $\mathrm{S}$ & $\mathrm{S}$ & $\mathrm{S}$ & I & $\mathrm{R}$ & I & $\mathrm{S}$ & $\mathrm{S}$ & $\mathrm{S}$ \\
\hline Bsb25 & $S$ & S & $S$ & $\mathrm{~S}$ & S & S & $\mathrm{R}$ & I & $\mathrm{S}$ & S & I & I & $S$ \\
\hline Bsb26 & $\mathrm{R}$ & I & $\mathrm{R}$ & I & I & I & S & S & $\mathrm{S}$ & S & S & S & $\mathrm{S}$ \\
\hline Bsb28 & $\mathrm{R}$ & S & $S$ & $\mathrm{~S}$ & S & I & $\mathrm{R}$ & $\mathrm{R}$ & $\mathrm{R}$ & $\mathrm{R}$ & $\mathrm{R}$ & $\mathrm{R}$ & I \\
\hline Bsb30 & $\mathrm{S}$ & $\mathrm{S}$ & $\mathrm{S}$ & $\mathrm{S}$ & $\mathrm{S}$ & $\mathrm{S}$ & $\mathrm{S}$ & $\mathrm{S}$ & $\mathrm{S}$ & $\mathrm{S}$ & $\mathrm{S}$ & $\mathrm{S}$ & $\mathrm{S}$ \\
\hline Bsb51 & S & S & S & $\mathrm{S}$ & S & $S$ & S & S & $\mathrm{S}$ & S & S & S & $\mathrm{S}$ \\
\hline Bsb64 & S & $\mathrm{S}$ & $\mathrm{S}$ & S & S & $\mathrm{S}$ & $\mathrm{R}$ & $\mathrm{R}$ & $\mathrm{R}$ & $\mathrm{R}$ & $\mathrm{R}$ & $\mathrm{R}$ & $\mathrm{R}$ \\
\hline Bsb67 & $\mathrm{R}$ & S & S & $\mathrm{S}$ & S & I & S & S & $\mathrm{S}$ & S & S & S & $\mathrm{S}$ \\
\hline Bsb78 & $\mathrm{S}$ & $\mathrm{S}$ & $\mathrm{S}$ & $\mathrm{S}$ & $\mathrm{S}$ & $\mathrm{S}$ & $\mathrm{S}$ & $\mathrm{S}$ & I & $\mathrm{S}$ & $\mathrm{S}$ & $\mathrm{S}$ & $\mathrm{S}$ \\
\hline Bsb79 & $\mathrm{S}$ & $\mathrm{S}$ & $\mathrm{S}$ & $\mathrm{S}$ & $\mathrm{S}$ & $\mathrm{S}$ & $\mathrm{S}$ & $\mathrm{S}$ & I & $\mathrm{S}$ & $\mathrm{S}$ & $\mathrm{S}$ & $\mathrm{S}$ \\
\hline Bsb82 & $S$ & S & S & S & S & $S$ & S & S & S & S & S & S & S \\
\hline Bsb87 & S & S & S & $\mathrm{S}$ & S & S & S & S & S & S & S & S & $\mathrm{S}$ \\
\hline Bsb88 & $S$ & S & S & $\mathrm{S}$ & S & $S$ & $\mathrm{R}$ & $\mathrm{R}$ & I & $S$ & I & I & S \\
\hline
\end{tabular}

* S: susceptible; I: intermediate resistance; R: resistant;

** APV: amprenavir; IDV: indinavir; NFV: nelfinavir; RTV: ritonavir; SQV: saquinavir; LPV: lopinavir; 3TC: lamivudine; ABC: abacavir; AZT: zidovudine; D4T: stavudine; DDC: zalcitabine; DDI: didanosine; TDF: tenofovir.

the virus population of a person infected with a RNA virus, we detected many polymorphisms in the sequences analyzed. The most common PR polymorphism in our study was N37S (73.7\%) followed by the accessory mutation L63P (36.8\%). L63P was also frequent (54 and 76\%) in previous Brazilian studies $(6,9)$. Codon 63 is the most polymorphic protease position: in untreated persons, about $45 \%$ have $63 \mathrm{P}$ and the prevalence of amino acids other than $\mathrm{L}$ increases to $90 \%$ in heavily treated patients (34). The high frequency $(63.2 \%)$ of substitutions at the RT position I135 is in agreement with the proportion of $72.3 \%$ of mutations at this same position detected in drug-naïve HIV-1 positive individuals in a previous Brazilian study (9). Other changes detected in RT sequences, as R211K (26.3\%) and L214F/Y (26.3\%) were also found by Brindeiro et al. (6) at frequencies of $48.7 \%$ and $20.5 \%$, respectively.

The prevalence of major resistance mutations for any drug observed among recent seroconverters differs from country to country. It ranges from 5 to $11 \%$ in Switzerland, 4 to $17 \%$ in France, $13 \%$ in Germany, $14 \%$ in the United Kingdom, 2 to $26 \%$ in North America, and 23 to $26 \%$ in Spain. As our data were not obtained from recent seroconverters but from individuals experiencing therapeutical failure, the prevalence of resistance mutations for any drug observed in the studied population was high $(84.2 \%)$. Information on antiretroviral-associated mutations in HIV-1 infected individuals in Brazil is limited and data about one geographical area cannot be extrapolated to the others. Most of this information belongs to drug-naïve individuals and have shown a low prevalence of mutations related to PI, NRTI, and NNRTI (9).

A previous report of HIV-1 resistance in drug-naïve infected individuals in Brazil described a lack of resistant strains harboring major mutations and a higher frequency $(85 \%)$ of accessory mutations, mainly in the PR region (9). Another report of HIV-1 isolates from Brazilian children failing therapy described the frequency of $44.23 \%$ of PR genotypes resistant to PI and $96.15 \%$ of RT genotypes resistant to NRTI and/or NNRTI (6). In our study, $63.2 \%$ of PR and $57.9 \%$ of RT sequences showed antiretroviral resistance-associated substitutions. A factor that may contribute to the different frequencies of resistance mutations among studies is the population analyzed, as drug selective pressure might drive the evolution of resistance mutations in HIV-1 strains from treated individuals.

Each new NRTI-resistant mutation confers a greater level of resistance than the accumulation of mutations within the PR gene. These PR mutations may improve fitness but have limited or no effect on susceptibility to PI. In fact, multiple mutations 
appear to be necessary for the development of a highly PIresistant virus $(8,22)$. Accordingly, among PI, we detected seven samples $(36.8 \%)$ resistant to APV and one sample $(5.3 \%)$ resistant to NFV, while all NRTI had at least one sample classified as resistant. This also supports the fact that development of resistance is the result of a complex combination of factors, including the size and heterogeneity of the HIV-1 population within an individual, the extent to which virus replication continues during drug therapy, the ease of acquisition of a particular mutation (or set of mutations), and the effect of drug resistance mutations on drug susceptibility and virus fitness (27).

In summary, this study has shown that $84.2 \%$ of the HIV infected subjects failing therapy in the studied population of Federal District presented viral genomic mutations associated with drug resistance. This result is in agreement with the data reported in a recent study of Brazilian patients, where $84.7 \%$ of the population analyzed showed resistance-associated mutations (30). A high prevalence of polymorphisms at positions associated with resistance to PI and NRTI was observed, supporting the high degree of genetic diversity of PR and RT genes in individuals failing treatment. Our results therefore emphasize the importance of detecting the circulation of HIV-1 drug-resistant strains, polymorphisms and genetic subtypes for control and treatment of HIV-1 disease, establishing the relevance of molecular epidemiological surveillance systems. This might provide supporting evidence of biologic differences in transmissibility, pathogenesis, and resistance profiles of HIV-1.

\section{ACKNOWLEDGEMENTS}

The authors thank John Penney for reviewing this manuscript. Financial Support: FINATEC. Daniela Marreco Cerqueira was the recipient of a fellowship from $\mathrm{CNPq}$.

\section{RESUMO}

\section{Subtipos e mutações associadas à resistência aos anti-retrovirais em isolados de HIV-1 do Distrito Federal}

A detecção de polimorfismos do HIV-1 que estejam associados à resistência às drogas anti-retrovirais e aos subtipos genéticos é importante para o controle e tratamento da infecção pelo HIV-1. A pressão exercida pela terapia anti-retroviral seleciona variantes resistentes com mutações nos genes virais da transcriptase reversa (RT) e da protease (PR). Assim, visando contribuir com as autoridades de saúde pública na perspectiva de planejar a disponibilidade de um tratamento terapêutico, nós descrevemos a variabilidade genética e a prevalência de mutações associadas à resistência aos anti-retrovirais em isolados do HIV-1 de indivíduos infectados no Distrito Federal.
Dezenove amostras de RNA do HIV-1 provenientes de um laboratório de Saúde Pública do Distrito Federal foram transcritas reversamente e os cDNAs obtidos foram amplificados por nested PCR. Um fragmento de 297 pb correspondente ao gene completo da protease e outro de $647 \mathrm{pb}$, correspondente à parte do gene da transcriptase reversa (códons 19 a 234), foram obtidos. O seqüenciamento automático e análise de homologia revelaram a presença de 17 subtipos B e 2 subtipos F1 do HIV-1. As sequiências de aminoácidos foram analisadas com relação à presença de mutações associadas à resistência. Um total de 6 mutações na PR, 2 primárias e 4 secundárias e 8 mutações relacionadas à resistência na RT foram encontradas. Nossos dados sugerem uma elevada prevalência do subtipo B do HIV1 na população estudada do Distrito Federal, assim como a presença de variantes virais geneticamente resistentes em indivíduos que não respondem ao tratamento.

Palavras-chave: HIV-1, resistência às drogas, drogas antiretrovirais

\section{REFERENCES}

1. Aleman, S.; Söderbärg, K.; Visco-Comandini, U.; Sitbon, G.; Sönnerborg, A. Drug resistance at low viraemia in HIV-1 infected patients with antiretroviral combination therapy. AIDS, 16:1039-1044, 2002.

2. Altschul, S.F.; Gish, W.; Miller, W.; Myers, E.W.; Lipman, D.J. Basic local alignment search tool. J. Mol. Biol., 215(13):403-410, 1990

3. Apetrei, C.; Descamps, D.; Collin, G.; Loussert-Ajaka, I.; Damond, F.; Duca, M.; Simon, F.; Brun-Vézinet, F. Human Immunodeficiency Virus Type 1 Subtype F Reverse Transcriptase Sequence and Drug Susceptibility. J. Virol., 72(5):3534-3538, 1998.

4. Arens, M. Clinically relevant sequence-based genotyping of HBV, HCV, CMV, and HIV. J. Clin. Virol., 22:11-29, 2001.

5. Brasil, Ministério da Saúde, Coordenação Nacional de DST e Aids, 2003. Available at: http://www.aids.gov.br.html

6. Brindeiro, P.A.; Brindeiro, R.M.; Mortensen, C.; Hertogs, K.; De Vroey, V.; Rubini, N.P.; Sion, F.S.; de As C.A.; Machado, D.M.; Succi, R.C.; Tanuri, A. Testing genotypic and phenotypic resistance in human immunodeficiency virus type 1 isolates of clade B and other clades from children failing antiretroviral therapy. J. Clin. Microbiol. 40(12):4512-9, 2002.

7. Brown, A.J.; Precious, H.M.; Whitcomb, J.M.; Wong, J.K.; Quigg, M.; Huang, W.; Daar, E.S.; D’Aquila R.T.; Keiser, P.H.; Connick, E.; Hellmann, N.S.; Petropoulos, C.J.; Richman, D.D.; Little, S.J. Reduced susceptibility of human immunodeficiency virus type 1 (HIV-1) from patients with primary HIV infection to nonnucleoside reverse transcriptase inhibitors is associated with variation at novel amino acid sites. J. Virol., 74(22):10269-73, 2000.

8. Cabana, M.; Fernàndez, G.; Parera, M.; Clotet, B.; Martínez, M.A Catalytic Efficiency and Phenotype of HIV-1 Proteases Encoding Single Critical Resistance Substitutions. Virology, 300:71-78, 2002.

9. Dumans, A.T.; Soares, M.A.; Pieniazek, D.; Kalish, M.L.; Vroey, V.D.; Hertogs, K.; Tanuri, A. Prevalence of Protease and Reverse Transcriptase Drug Resistance Mutations over Time in Drug-Naïve Human Immunodeficiency Virus Type 1-Positive Individuals in Rio de Janeiro, Brazil. Antimicrob. Agents Chemother., 46(9):3075-3079, 2002.

10. Dykes, C.; Fox, K.; Lloyd, A.; Chiulli, M.; Morse, E.; Demeter, L.M. Impact of Clinical Reverse Transcriptase Sequences on the 
Replication Capacity of HIV-1 Drug-Resistant Mutants. Virology, 285:193-203, 2001.

11. Frater, A.J.; Chaput, C.C.; Beddows, S.; Weber, J.N.; McClure, M.O. Simple detection of point mutations associated with HIV-1 drug resistance. J. Virol. Methods, 93:145-156, 2001.

12. Gonzales, M.J.; Machekano, R.N.; Shafer, R.W. Human Immunodeficiency Virus Type 1 Reverse-Transcriptase and Protease Subtypes: Classification, Amino Acid Mutation Patterns, and Prevalence in a Northern California Clinic-Based Population. J. Infect. Dis., 184:998-1006, 2001.

13. Hirsch, M.S.; Brun-Vézinet, F.; D’Aquila, R.T.; Hammer, S.M.; Johnson, V.A.; Kuritzkes, D.R.; Loveday, C.; Mellors, J.W.; Clotet, B.; Conway, B.; Demeter, L.M.; Vella, S.; Jacobsen, D.M.; Richman, D.D. Antiretroviral Drug Resistance Testing in Adult HIV-1 Infection. JAMA, 283(18):2417-2426, 2000.

14. Hirsch, M.S.; Conway, B.; D'Aquila, R.T.; Johnson, V.A.; BrunVézinet, F.; Clotet, B.; Demeter, L.M.; Hammer, S.M.; Jacobsen, D.M.; Kuritzkes, D.R.; Loveday, C.; Mellors, J.W.; Vella, S.; Richman, D.D. Antiretroviral Drug Resistance Testing in Adults With HIV Infection. JAMA, 279(24):1984-1991, 1998.

15. Holguín, A.; Álvarez, A.; Soriano, V. High prevalence of HIV-1 subtype $\mathrm{G}$ and natural polymorphisms at the protease gene among HIVinfected immigrants in Madrid. AIDS, 16:1163-1170, 2002.

16. Magiorkinis, E.; Paraskevis, D.; Magiorkinis, G.; Chryssou, S.; Chini, M.; Lazanas, M.; Paparizos, V.; Saroglou, G.; Antoniadou, A.; Giamarellou, E.; Karafoulidou, A.; Hatzakis A. Mutations associated with genotypic resistance to antiretroviral therapy in treatment naïve HIV-1 infected patients in Greece. Virus Res., 85:109-115, 2002.

17. Martínez, A.M.B.; Barbosa, E.F.; Ferreira, P.C.P.; Cardoso, F.A.; Silveira, J.; Sassi, G.; Silva, C.M.; Mendonça-Signorini, V.; Antunes, C.M.F. Molecular epidemiology of HIV-1 in Rio Grande, RS, Brazil. Rev. Soc. Bras. Med. Trop., 35(5):471-476, 2002.

18. Morgado, M.G.; Guimarães, M.L.; Galvão-Castro, B. HIV-1 Polymorphism: a Challenge for Vaccine Development - A Review. Mem. Inst. Oswaldo Cruz, 97(2):143-150, 2002.

19. Morgado, M.G.; Guimarães, M.L.; Neves, Jr.; Veloso dos Santos, V.G.; Linhares-de-Carvalho, M.I.; Castello-Branco, L.R.; Bastos, F.I.; Castilho, E.A.; Galvão-Castro, B.; Bongertz, V.; The Hospital Evandro Chagas AIDS Clinical Research Group. Molecular Epidemiology of HIV in Brazil: Polymorphism of the Antigenically Distinct HIV-1 B Subtype Strains. Mem. Inst. Oswaldo Cruz, 93(3):383-386, 1998.

20. Papa, A.; Papadimitriou, E.; Papoutsi, A.; Kiosses, V.; Antoniadis, A. HIV-1 subtypes and circulating recombinant forms (CRFs) in Northern Greece. Virus Res., 85:85-93, 2002.

21. Peduzzi, C.; Pierotti, P.; Venturi, G.; Romano, L.; Mazzotta, F.; Zazzi, M. Performance of an in-house genotypic antiretroviral resistance assay in patients pretreated with multiple human immunodeficiency virus type 1 protease and reverse transcriptase inhibitors. J. Clin. Virol., 25:57-62, 2002.

22. Quiñones-Mateu, M.E.; Arts, E.J. HIV-1 Fitness: Implications for Drug Resistance, Disease Progression, and Global Epidemic Evolution.
In: Kuiken, C.; Foley, B.; Hahn, B.; Marx, P.; McCutchan, F.; Mellors, J.; Wolinsky, S.; Korber, B. (eds). HIV Sequence Compendium 2001. Theoretical Biology and Biophysics, New Mexico, 2001, p.134170 .

23. Ramos, A.; Tanuri, A.; Schechter, M.; Rayfield, M.A.; Hu, D.J.; Cabral, M.C.; Bandea, C.I.; Baggs, J.; Pieniazek, D. Dual and Recombinant Infections: An Integral Part of the HIV-1 Epidemic in Brazil. Emerg. Infect. Dis., 5(1):65-74, 1999.

24. Rosina, M.; Micheli, V.; Besana, S.; Toia, C.; Gismondo, M.R.; Cargnel, A. Genotyping in HIV drug resistance mutations: epidemiology in 145 patients. Int. J. Antimicrob. Agents, 16:435-440, 2000.

25. Rossini, M.A.A.; Diaz, R.S.; Caseiro, M.; Turcato, G.; Accetturi, C.A.; Sabino, E.C. HIV-1 subtypes among intravenous drug users from two neighboring cities in São Paulo State, Brazil. Braz. J. Med. Biol. Res., 34(1):45-47, 2001.

26. Sabino, E.C.; Diaz, R.S.; Brigido, L.F.; Learn, G.H.; Mullins, J.L.; Reingold, A.L.; Duarte, A.J.; Mayer, A.; Busch, M.P. Distribution of HIV-1 subtypes seen in an AIDS clinic in São Paulo City, Brazil. AIDS, 10:1579-1584, 1996

27. Shafer, R.W. Genotypic Testing for Human Immunodeficiency Virus Type 1 Drug Resistance. Clin. Microbiol. Rev., 15(2):247-277, 2002.

28. Shafer, R.W.; Jung, D.R.; Betts, B.J. Human immunodeficiency virus type 1 reverse transcriptase and protease mutation search engine for queries. Nat. Med., 6:1290-1292, 2000.

29. Snoeck, J.; Dooren, S.V.; Laethem, K.V.; Derdelinckx, I.; Wijngaerden, E.V.; Clercq, E.D.; Vandamme, A-M. Prevalence and origin of HIV1 group $\mathrm{M}$ subtypes among patients attending a Belgian hospital in 1999. Virus Res., 85:95-107, 2002.

30. Tanuri, A.; Caridea, E.; Dantas, M.C.; Morgado, M.G.; Mello, D.L.C.; Borges, S.; Tavares, M.; Ferreira, S.B.; Santoro-Lopes, G.; Martins, C.R.F.; Esteves, A.L.C.; Diaz, R.S.; Andreo, S.M.S.; Ferreira, L.A.P.; Rodrigues, R.; Reuter, T.; Cavalcanti, A.M.S.; Oliveira, S.M.; Barbosa, H.B.; Teixeira, P.R.; Chequer, P.N. Prevalence of mutations related to HIV-1 antiretroviral resistance in Brazilian patients failing HAART. J. Clin. Virol., 25:39-46, 2002.

31. Tanuri, A.; Swanson, P.; Devare, S.; Berro, O.J.; Savedra, A.; Costa, L.J.; Telles, J.G.; Brindeiro, R.; Schable, C.; Pieniazek, D.; Rayfield, M. HIV-1 subtypes among blood donors from Rio de Janeiro, Brazil. J. Acquir. Immune Defic. Syndr. Hum. Retrovirol., 20:60-66, 1999.

32. Thompson, J.; Higgins, D.; Gibson, T. CUSTAL W: improving the sensitivity of progressive multiple sequence alignment through sequence weighting, position-specific gap penalties and weight matrix choice. Nucleic Acid Res., 22:4673-4680, 1994.

33. Wilson, J.W.; Bean, P.; Robins, T.; Graziano, F.; Persing, D.H. Comparative Evaluation of Three Human Immunodeficiency Virus Genotyping Systems: the HIV-GenotypR Method, the HIV PRT GeneChip Assay, and the HIV-1 RT Line Probe Assay. J. Clin. Microbiol., 38(8):3022-3028, 2000.

34. Yahi, N.; Tamalet, C.; Tourres, C.; et al. Mutation patterns of the reverse transcriptase and protease genes in human immunodeficiency virus type 1-infected patients undergoing combination therapy: survey of 787 sequences. J. Clin. Microbiol., 37:4099-106, 1999. 